\title{
TINJAUAN ASPEK ERGONOMI TATA RUANG PENYIMPANAN REKAM MEDIS DI RS HERMINA ARCAMANIK BANDUNG
}

\author{
Muti Lestari $^{1}$, Yuyun Yunengsih ${ }^{2}$, Sali Setiatin ${ }^{3}$ \\ Politeknik Piksi Ganesha Bandung, Indonesia ${ }^{1,2,3}$ \\ mlestari@piksi.ac.id ${ }^{1}$,yoen1903@gmail.com², salisetiatin@gmail.com
}

Received: 01-09-2021

Revised : 16-11-2021

Accepted: 18-11-2021

\begin{abstract}
Abstrak
Latar Belakang: Penataan ruang penyimpanan yang baik dibutuhkan untuk memudahkan pekerjaan petugas. Penataan ruang penyimpanan harus dilakukan berdasarkan aspek ergonomi.
\end{abstract}

Tujuan: Penelitian ini bertujuan untuk meninjau aspek ergonomi tata ruang penyimpanan rekam medis di RS Hermina Arcamanik Bandung.

Metode: Jenis penelitian ini menggunakan metode kualitatif dan dengan menggunakan pendekatan deskriptif. Cara pengumpulan data dengan metode observasi dan wawancara. Hasil: Hasil penelitian menunjukkan dari segi pengelolaan dan perlengkapan sudah sesuai dengan teori yang ada, hanya terdapat kendala pada ketersediaan jumlah alat bantu pijakan. Suhu di ruang penyimpanan sudah ideal, tingkat kebisingan rendah, dan pencahayaan sudah merata. Jenis dan ukuran rak rekam medis sudah ergonomi. Luas ruangan penyimpanan rekam medis belum ergonomi karena tidak sesuai dengan standar menurut ilmu ergonomi dan ruangan penyimpanan dokumen rekam medis terbagi menjadi dua ruangan yang terpisah. Jarak antar rak terbuka masih belum ergonomi karena petugas penyimpanan rekam medis masih kesulitan saat mengambil dan menyimpan berkas rekam medis karena jarak antar rak yang begitu sempit.

Kesimpulan: Berdasarkan hasil penelitian yang dilakukan di RS Hermina Arcamanik Bandung dapat disimpulkan bahwa Aspek ergonomi ruangan penyimpanan di RS Hermina Arcamanik Bandung dari segi pengelolaan dan perlengkapan sudah sesuai dengan teori yang ada, hanya terdapat kendala pada ketersediaan jumlah alat bantu pijakan. Suhu di ruang penyimpanan di RS Hermina Arcamanik Bandung sudah ideal, tingkat kebisingan rendah, dan pencahayaan sudah merata.

Kata kunci: aspek ergonomi; tata ruang; penyimpanan rekam medis.

\footnotetext{
Abstract

Background: A good arrangement of storage space is needed to facilitate the work of officers. The arrangement of storage space must be carried out based on ergonomic aspects.
} 


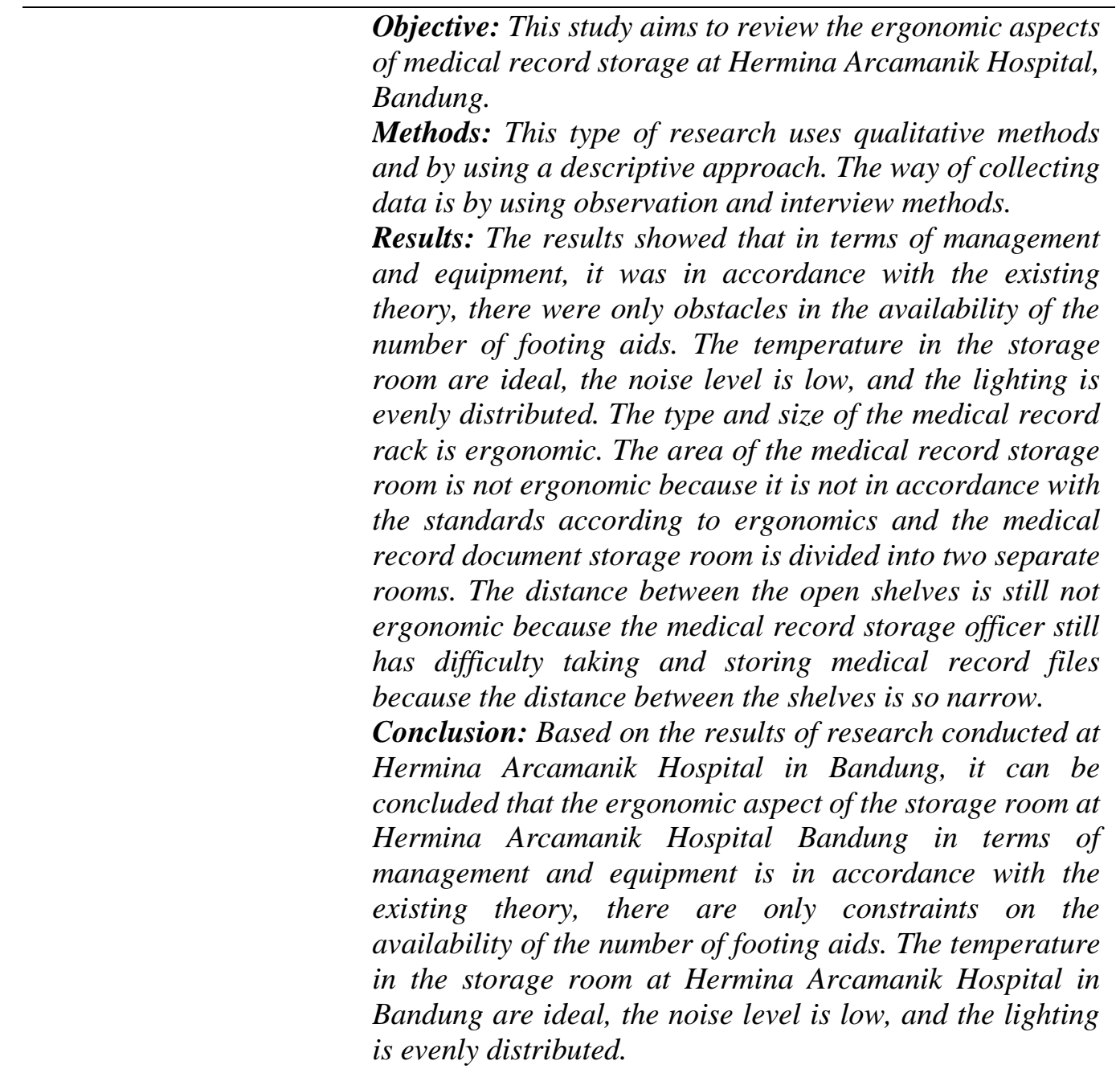

Keywords: ergonomics aspect; spatial; record storage medical.

*Correspondent Author: Muti Lestari Email: mlestari@piksi.ac.id

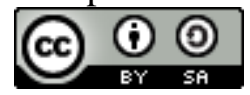

\section{PENDAHULUAN}

Agar fungsi rekam medis sebagai penyimpanan data dan informasi pelayanan pasien tetap terjaga kualitasnya, terdapat berbagai persyaratan yang harus tetap diperhatikan. Terdapat 6 faktor yang berkaitan dengan penyimpanan, ialah mudah di akses, bermutu, terpelihara keamanan (Security), fleksibilitas, bisa dihubungkan dengan bermacam sumber (Conn Eutivity), serta efektif (Hatta, 2013).

Penyimpanan berkas rekam kedokteran adalah salah satu bagian dari sistem rekam kedokteran rumah sakit. Dengan demikian, penyimpanan memiliki peranan yang sangat berarti dari bermacam data yang dipunyai oleh jasa pelayanan kesehatan. Dalam penerapan penyimpanan berkas rekam kedokteran dibutuhkan terdapatnya sarana yang mencukupi untuk berkas rekam kedokteran ataupun untuk petugas penerapan penyimpanan berkas rekam kedokteran. Banyak opsi yang ada dalam melaksanakan penjajaran rekam kedokteran antara lain dengan menempatkan rekam kedokteran kedalam lemari terbuka (open solves), lemari kabinet (filing cabinet), ataupun dengan memakai teknologi Tinjauan Aspek Ergonomi Tata Ruang Penyimpanan Rekam Medis di Rs Hermina Arcamanik Bandung 
microfilm ataupun digital scanning serta terakhir secara komputerisasi (rekam kesehatan elektronik). Opsi terhadap metode yang digunakan bergantung pada kebutuhan serta sarana rumah sakit (Suardi \& Budi, 2013).

Budi (2011:93) mengemukakan ruang penyimpanan rekam medis merupakan suatu tempat untuk penyimpanan berkas rekam medis pasien rawat jalan, rawat inap dan merupakan salah satu bagian dari unit rekam medis yang bertanggung jawab dalam penyimpanan dan pengembalian rekam medis (Djohar, Oktavia, \& Damayanti, 2018). Sebagaimana meneurut (Murodi, 2018) berpendapat bahwa ergonomi merupakan kajian interaksi antara manusia dan mesin, serta faktor-faktor yang mempengaruhinya . Tujuannya adalah mencapai sistem kerja yang produktif dan kualitas yang terbaik, disertai dengan kemudahan, kenyamanan, dan efisiensi kerja, tanpa mengabaikan kesehatan dan keselamatan kerja (Harahap, 2019).

Ergonomi adalah ilmu dan pelaksanaannya yang berupaya untuk menyerasikan pekerjaan dan zona terhadap orang maupun sebaliknya dengan tujuan tercapainya produktivitas dan efisiensi yang setinggi tingginya melalui pemanfaatan manusia seoptimal- optimalnya (Hutabarat, 2017). Upaya antara lain berbentuk membiasakan dimensi tempat kerja dengan ukuran badan supaya tidak meletihkan. Pengaturan suhu, cahaya, bertujuan agar sesuai dengan kebutuhan tubuh manusia (프, 2006). Beberapa perbaikan ergonomi yang telah dilakukan oleh para ahli di luar negeri, terbukti bahwa dengan penerapan ergonomi mampu memberikan keuntungan secara ekonomi, meningkatkan keselamatan dan kenyaman kerja. Pengendalian ergonomi digunakan untuk menyesuaikan tempat kerja dengan pekerja supaya badan pekerja terletak di posisi yang baik dan mengurangi efek kerja (Jepisah, 2020).

Hasil penelitian Pusat Penelitian Penyakit Tidak Menular Badan Lembaga Kesehatan Depkes RI menyatakan, akibat dari pemakaian fasilitas kerja yang tidak ergonomis akan menyebabkan perasaan tidak nyaman, kurang konsentrasi, mengantuk, dan lain sebagainya. Kondisi kerja yang buruk berpotensi menjadi penyebab karyawan mudah jatuh sakit, mudah stres, sulit berkonsentrasi, dan menurunnya produktivitas kerja (Fanny, 2017). Kesesuaian ikatan antara antropometri pekerja dengan perlengkapan yang digunakan sangat mempengaruhi pada perilaku kerja, tingkatan keletihan, keahlian kerja serta produktivitas kerja (Tarwaka \& Sudiajeng, 2004).

Rustiyanto, E dan Rahayu W.A (2011) menyatakan bahwa hal-hal yang harus diperhatikan di dalam ruangan penyimpanan dokumen rekam medis yaitu suhu, luas ruangan penyimpanan/filing, jarak, aman, pencahayaan, debu, vektor penyakit (Rustiyanto \& Rahayu, 2011). Hal tersebut tentunya harus diperhatikan dikarenakan petugas akan bekerja secara terus menerus di tempat kerja, dengan tempat kerja yang nyaman serta ruang gerak petugas yang efisien maka kinerja petugas pun bisa optimal serta meminimalisir terjadinya kelelahan akibat kerja. Sedangkan jarak ideal untuk akses jalan petugas antara satu rak lemari dengan rak lemari lainnya menurut Rustiyanto (2011) kurang lebih $180 \mathrm{~cm}$ $-200 \mathrm{~cm}$, sedangkan lorong di bagian sub rak $80 \mathrm{~cm}-100 \mathrm{~cm}$. Jarak antara 2 buah rak untuk lalu lalang dianjurkan selebar $90 \mathrm{~cm}$ (Depkes RI, 2014).

Berdasarkan pengalaman praktik kerja lapangan pada semester 6 yang peneliti lakukan di ruang penyimpanan rekam medis di RS Hermina Arcamanik Bandung, peneliti melihat pengelolaan rekam medisnya cukup baik, akan tetapi ada beberapa permasalahan yaitu ruang penyimpanan berkas rekam medis di RS Hermina Arcamanik Bandung dibagi menjadi dua ruangan dan masing-masing ruangan berada pada lokasi yang terpisah yaitu ruangan di lantai 5 , ruangan ini adalah tempat ruang kerja petugas rekam medis dan di dalam ruangan ini terdapat 130 rak terbuka sebagai tempat penyimpanan berkas rekam medis aktif, kemudian ruangan di lantai 6 , ruangan ini adalah tempat ruang kerja khusus kepala bagian rekam medis dan di dalam ruangan ini terdapat 30 rak terbuka sebagai tempat penyimpanan berkas rekam medis aktif dan terdapat banyak berkas rekam medis inaktif yang disimpan di lantai. Dengan ruangan penyimpanan yang terpisah tentu membuat 
petugas rekam medis memerlukan waktu yang cukup lama saat pengambilan berkas rekam medis pasien yang berada di lantai 6 karena petugas harus naik ke lantai 6 menggunakan tanggal lift untuk mengambil berkas rekam medis yang dibutuhkan.

Masih banyak berkas rekam medis yang di simpan di lantai/kardus tidak pada rak penyimpanan, jarak antar rak yang begitu sempit, dokumen rekam medis yang tersimpan di rak dengan tidak rapi serta masih banyak dokumen rekam medis yang sengaja dipaksa dimasukan pada rak meskipun rak sudah penuh. Sehingga menyulitkan ruang gerak petugas karena jarak antar rak yang begitu sempit dan petugas kesulitan saat melakukan pengambilan dan penyimpanan secara bersamaan, serta menimbulkan risiko dokumen rekam medis mudah robek maupun jatuh ketika tersenggol petugas rekam medis pada saat pengambilan dan penyimpanan dokumen rekam medis.

Tidak disediakan tangga/kursi pijakan di setiap lorong antar rak sehingga mengharuskan petugas memanjat rak untuk mengambil rekam medis yang tidak terjangkau. Hal tersebut kurang aman sehingga memungkinkan adanya risiko jatuh, terkilir dan sebagainya. Selain itu juga berdasarkan hasil wawancara kepada salah satu petugas di tempat penyimpanan dokumen rekam medis bahwa petugas mengeluhkan merasa pengap saat bekerja. Penelitian ini bertujuan menentukan aspek ergonomi tata ruang penyimpanan rekam medis di RS HERMINA Arcamanik Bandung.

Pada penelitian yang dilakukan oleh (Mathar, Nurlina, \& Puspa, 2019) membahas tentang perancangan ergonomi di ruang filing yang membantu dalam pekerjaan rekam medis. Sedangkan penelitian tersebut tidak menjelaskan tentang ruangan tersebut apakah sudah ergonomi atau belum. Pentingnya penelitian ini yaitu untuk mengetahui apakah ruang penyimpanan di RS Hermina Arcamanik sudah memenuhi ergonomi atau belum. Ergonomi sangat penting untuk kenyamanan dan keamanan dalam bekerja. Berdasarkan permasalahan diatas menjadi dasar pertimbangan peneliti untuk melakukan penelitian dengan judul "Tinjauan Aspek Ergonomi Tata Ruang Penyimpanan Rekam Medis di RS Hermina Arcamanik Bandung“.

\section{METODE PENELITIAN}

Jenis penelitian yang digunakan adalah deskriptif kualitatif. Penelitian deskriptif kualitatif yaitu penelitian yang tidak menggunakan angka-angka statistik tetapi mendeskripsikan dengan kata-kata keadaan di lapangan (Subandi, 2011). Konsep penelitian ini adalah aspek ergonomi tata ruang penyimpanan rekam medis.

Populasi ialah daerah generalisasi yang terdiri dari objek/subjek yang mempunyai kuantitas serta ciri tertentu yang diresmikan oleh periset agar dipelajari serta setelah itu ditarik kesimpulannya (Siyoto \& Sodik, 2015). Populasi penelitian ini adalah petugas yang berada di unit rekam medis. Pengertian sampel menurut Notoatmojo (2018) adalah sebagian objek yang diambil dari keseluruhan objek yang diteliti dan dianggap mewakili seluruh populasi (Notoamodjo Soekidjo, 2018). Sampel dalam penelitian ini menggunakan Total Sampling yaitu semua populasi menjadi sampel.

Instrumen penelitian menggunakan alat perekam sebagai alat bantu dalam melakukan pengumpulan data, meteran, dan wawancara. Waktu penelitian dilaksanakan pada bulan April-Juni 2021 di ruang penyimpanan rekam medis RS Hermina Arcamanik Bandung. Cara pengumpulan data dengan cara observasi dan wawancara bertujuan untuk mengamati dan mengetahui gambaran tata ruang penyimpanan rekam medis berdasarkan aspek ergonomi di RS Hermina Arcamanik Bandung.

\section{HASIL DAN PEMBAHASAN}

Tinjauan Aspek Ergonomi Tata Ruang Penyimpanan Rekam Medis di Rs Hermina Arcamanik Bandung 


\section{A. Hasil Penelitian}

Penulis telah melakukan pengamatan dan pengukuran terhadap aspek ergonomi tata ruang penyimpanan rekam medis, serta wawancara terhadap kepala bagian rekam medis dan petugas pengambilan dan penyimpanan rekam medis. Adapun item-item yang dilakukan pengamatan, pengukuran dan wawancara adalah sebagai berikut:

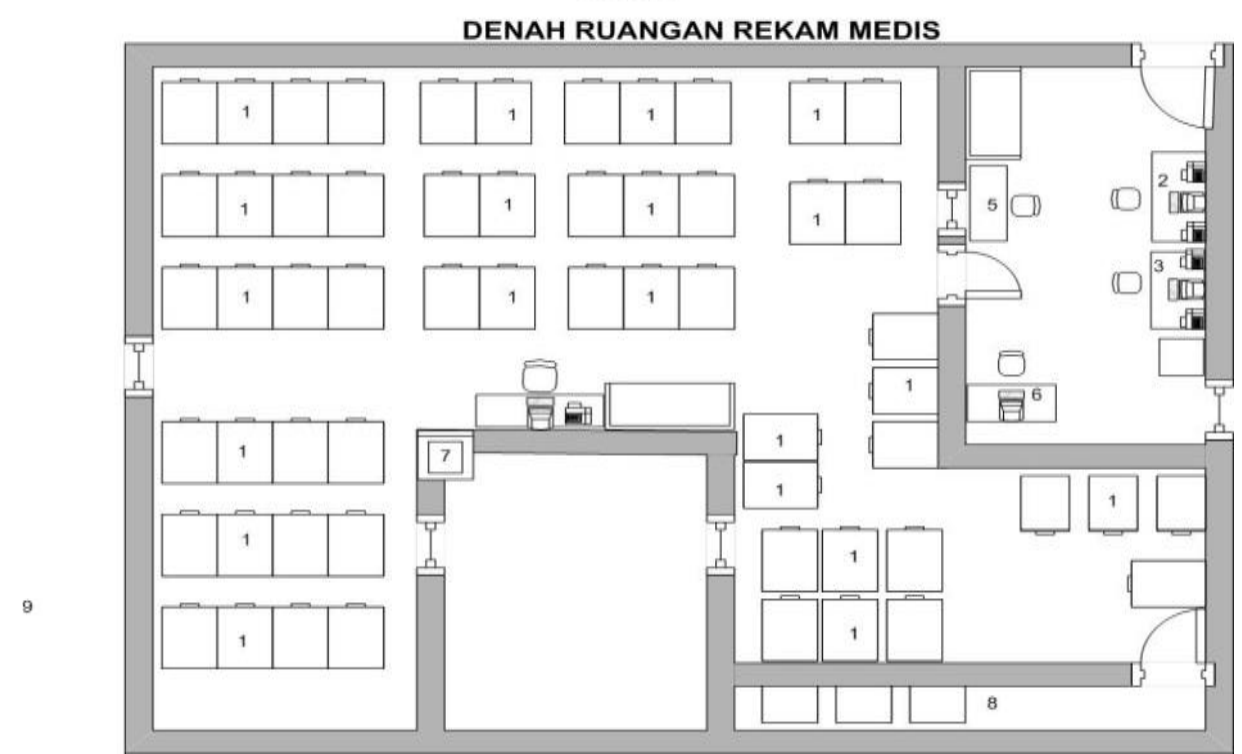

Gambar 1.1 Denah letak ruangan rekam medis di RS Hermina Arcamanik Bandung

Keterangan denah ruangan rekam medis:

1. Rak penyimpanan rekam medis

2. Meja pengolahan rekam medis pasien baru

3. Meja pengolahan rekam medis rawat inap (input diagnosa, statistik)

4. Meja pengolahan rekam medis rawat jalan

5. Meja assembling

6. Meja pengolahan pelaporan rekam medis

7. Dumbwaiter ( lift sirkulasi berkas rekam medis lantai 1, lantai 2 dan lantai perawatan )

8. Rak penyimpanan non aktif

9. Ruangan KTK

Ergonomi Ruang Penyimpanan di Unit Rekam Medis RS Hermina Arcamanik Bandung

1) Pengelolaan dan Perlengkapan di Ruang Penyimpanan Rekam Medis

a) Struktur Bangunan

Struktur bangunan ruang penyimpanan di RS Hermina Arcamanik Bandung kuat terpelihara dan bersih.

b) Atap

Atap ruang penyimpanan di RS Hermina Arcamanik Bandung kuat dan tidak bocor.

c) Dinding

Dinding ruang filing di RS Hermina Arcamanik Bandung kuat dan berwarna terang.

d) Langit-Langit

Langit-langit ruang penyimpanan di RS Hermina Arcamanik Bandung kuat, bersih dan berwarna terang.

e) Lantai

Lantai ruang penyimpanan di RS Hermina Arcamanik kuat, kedap air, permukaan rata, bersih dan tidak licin.

Tinjauan Aspek Ergonomi Tata Ruang Penyimpanan Rekam Medis di Rs Hermina

Arcamanik Bandung 
f) Keamanan Rekam Medis

Terdapat alat Access Control khusus petugas rekam medis di depan pintu ruang penyimpanan rekam medis untuk menjamin kerahasiaan isi rekam medis.

g) Vektor Penyakit

Tidak terindikasi adanya sarang hewan yang merupakan vektor (pembawa) penyakit seperti serangga (kecoa, lalat, nyamuk) dan tikus di ruang penyimpanan RS Hermina Arcamanik Bandung.

h) Debu

Debu di ruangan penyimpanan juga harus kita perhatikan, agar kandungan debu di dalam udara ruang penyimpanan memenuhi persyaratan kesehatan maka perlu dilakukan upaya-upaya sebagai berikut :

(1) Kegiatan membersihkan ruangan penyimpanan dilakukan pada pagi dan sore hari dengan menggunakan kain pel basah atau pompa hampa (vacuum pump ).

(2) Sistem ventilasi yang memenuhi syarat.

i) Petunjuk Penyimpanan

Petunjuk Penyimpanan rekam medis di RS Hermina Arcamanik Bandung menggunakan stiker nomor yang ditempelkan di setiap sisi samping rak penyimpanan. Stiker nomor tersebut mudah digunakan dan dilihat.

j) Kode Warna Rekam Medis

Rekam Medis di RS Hermina Arcamanik Bandung menggunakan kode warna dalam bentuk stiker untuk dua digit terakhir nomor rekam medis pasien.

k) Mesin Penghancur Kertas

RS Hermina Arcamanik Bandung tidak mempunyai mesin penghancur kertas karena pemusnahan rekam medis dilakukan oleh pihak ketiga.

1) Wastafel dan cairan pencuci tangan, masker, air galon

Wastafel dan cairan pencuci tangan, masker, air galon di dalam ruangan penyimpanan RS Hermina Arcamanik Bandung sudah disediakan.

m) Alat Bantu Pijakan

Alat bantu pijakan di ruang penyimpanan RS Hermina Arcamanik Bandung adalah tangga yang terbuat dari bahan aluminium, namun jumlahnya hanya ada 2 buah, sehingga setiap lorong antar rak tidak disediakan tangga untuk alat bantu pijakan.

n) Suhu

Hasil penelitian di ruang penyimpanan rekam medis RS Hermina Arcamanik Bandung yaitu ada AC (Air Conditioner) dan ventilasi. Suhu udara untuk menggunakan AC sebaiknya $22-26{ }^{\circ} \mathrm{C}$ dan suhu udara untuk ruangan yang tidak ber AC berkisar antara $18-28^{\circ} \mathrm{C}$.

Tabel 1. Hasil Pengukuran Suhu di Ruang Penyimpanan RS Hermina Arcamanik Bandung

\begin{tabular}{cl}
\hline Waktu & Suhu \\
\hline Pagi $(07.00-14.00)$ & $24^{\circ} \mathrm{C}$ \\
\hline Siang $(14.00-21.00)$ & $25^{\circ} \mathrm{C}$ \\
\hline Sore $(15.00-21.00)$ & $24^{\circ} \mathrm{C}$ \\
\hline
\end{tabular}

Sumber: Data Sekunder

Berdasarkan tabel 1 di atas menunjukkan bahwa suhu di ruang penyimpanan RS Hermina Arcamanik Bandung sudah ideal menurut teori Rustiyanto dan Warih Ambar (2011) adalah $18-28{ }^{\circ} \mathrm{C}$ (Rustiyanto \& Rahayu, 2011). Adapun rata-rata suhu di ruang penyimpanan RS Hermina Arcamanik Bandung adalah $24,3{ }^{\circ} \mathrm{C}$.

Tinjauan Aspek Ergonomi Tata Ruang Penyimpanan Rekam Medis di Rs Hermina Arcamanik Bandung 
o) Pencahayaan dan Kebisingan

Menurut (Darmawan, Roziqin, \& Erawantini, 2020) bahwa lingkungan fisik tempat kerja bagi manusia salah satunya dipengaruhi oleh cahaya. Pencahayaan di dalam ruang bangunan rumah sakit adalah intensitas penyinaran pada suatu bidang kerja yang ada di dalam ruang bangunan rumah sakit untuk melaksanakan kegiatan secara efektif. Pencahayaan dan kebisingan tidak diukur secara ilmiah oleh peneliti karena keterbatasan alat ukur. Berdasarkan hasil pengamatan pencahayaan di ruang penyimpanan RS Hermina Arcamanik Bandung di setiap lorong ruang penyimpanan rekam medis cukup terang. Karena setiap lampu ditempatkan di setiap lorong rak penyimpanan. Adapun ruang penyimpanan di RS Hermina Arcamanik Bandung memiliki tingkat kebisingan yang rendah, mengingat ruang penyimpanan cukup tertutup. Hal tersebut sesuai dengan standar ILO (2013). Rendahnya tingkat kebisingan di ruang penyimpanan RS Hermina Arcamanik Bandung baik untuk mendukung kesehatan kerja petugas terutama berkaitan dengan gangguan pendengaran, baik gangguan pendengaran sementara ataupun permanen.

2) Jenis dan ukuran rak ruangan penyimpanan rekam medis di RS Hermina Arcamanik

Berdasarkan hasil pengamatan, di dalam ruangan penyimpanan rekam medis di RS Hermina Arcamanik Bandung menggunakan rak penyimpanan rekam medis dengan jenis rak terbuka yang terbuat dari bahan besi dan kayu. Rak terbuka adalah lemari yang tidak berpintu yang dapat digunakan untuk menyimpan berkas pasien. Standar ideal untuk rak terbuka yaitu panjang $1,15 \mathrm{~m}$, lebar $0,4 \mathrm{~m}$, tinggi $2,1 \mathrm{~m}$. Satu sub rak terdiri dari 8 kotak ukuran masing-masing sub rak yaitu panjang $1,15 \mathrm{~m}$, lebar $0,4 \mathrm{~m}$, tinggi $0,3 \mathrm{~m}$.

Adapun hasil pengukuran fisik terhadap rak penyimpanan berkas rekam medis di RS Hermina Arcamanik Bandung adalah sebagai berikut:

Tabel 2. Hasil Pengukuran Rak Penyimpanan

\begin{tabular}{cll}
\hline No & Peralatan & Ukuran $(\mathbf{c m})$ \\
\hline 1 & Panjang rak penyimpanan & 249,5 \\
\hline 2 & Tinggi rak penyimpanan & 250 \\
\hline 3 & Lebar rak penyimpanan & 50 \\
\hline 4 & Tinggi sub rak penyimpanan & 40 \\
\hline 5 & Lebar sub rak penyimpanan & 26 \\
\hline
\end{tabular}

Sumber : Data Primer

3) Luas Ruangan penyimpanan berkas rekam medis di RS Hermina Arcamanik

Bandung

Berdasarkan hasil penelitian di lapangan, ruangan penyimpanan berkas rekam medis di RS Hermina Arcamanik Bandung dibagi menjadi 2 ruangan yaitu ruangan penyimpanan rekam medis di lantai 5 dan ruangan penyimpanan rekam medis di lantai 6 serta ruangan yang di gabung dengan ruang kerja rekam medis. Luas ruangan merupakan hasil perhitungan panjang dikalikan lebar ruangan. Setelah dilakukan pengukuran maka ditemukan ukuran luas untuk ruangan lantai 5 yaitu $26 \mathrm{~m}^{2}$ dan untuk ruangan lantai 6 yaitu $23 \mathrm{~m}^{2}$.

Luas ruangan penyimpanan harus memadai (baik untuk rak berkas rekam medis aktif dan inaktif). Ruangan penyimpanan dokumen rekam medis aktif dan inaktif sebaiknya disendirikan, karena hal ini akan lebih mudah di dalam melaksanakan pemusnahan dokumen rekam medis (Rustiyanto \& Rahayu, 2011).

Berdasarkan hasil penelitian diatas, peneliti berasumsi bahwa luas ruangan penyimpanan di RS Hermina Arcamanik Bandung belum ergonomi karena tidak sesuai dengan standar menurut ilmu ergonomi dan ruangan penyimpanan dokumen rekam medis menjadi 2 ruangan yang terpisah. Luas ruangan pun masih sempit karena ruang Tinjauan Aspek Ergonomi Tata Ruang Penyimpanan Rekam Medis di Rs Hermina Arcamanik Bandung 
penyimpanan rekam medis digabung dengan ruang kerja rekam medis. Masih terdapat banyak berkas rekam medis yang letak tidak pada tempatnya sedangkan menurut teori luas ruangan penyimpanan harus memadai baik untuk berkas aktif dan inaktif dan luas ruangan sesuai dengan ilmu ergonomi.

4) Jarak antar rak penyimpanan berkas rekam medis di RS Hermina Arcamanik Bandung

Rumah sakit harus bisa mendesain ruangan penyimpanan rekam medis agar petugas di bagian penyimpanan tidak terlalu sempit sehingga akan mempengaruhi kenyaman petugas. Jarak antara rak penyimpanan yang satu dengan yang lainnya harus kita perhitungkan jangan sampai terlalu sempit atau terlalu lebar, sehingga akan memakan ruangan yang banyak. Jarak ideal untuk akses jalan petugas antara satu rak lemari dengan rak lemari lainnya kurang lebih $180 \mathrm{~cm}-200 \mathrm{~cm}$, sedang lorong di bagian sub rak $80 \mathrm{~cm}$ - $100 \mathrm{~cm}$ (Rustiyanto \& Rahayu, 2011). Menurut (DepKes, 2006), jarak antara dua buah rak untuk lalu-lalang dianjurkan selebar $90 \mathrm{~cm}$.

Jarak rata-rata antara satu rak dengan yang lain untuk ruang gerak petugas di ruang penyimpanan RS Hermina Arcamanik Bandung $65 \mathrm{~cm}$ sedangkan rata-rata lebar jalan untuk akses jalan petugas adalah sebesar $70 \mathrm{~cm}$. Berdasarkan hasil wawancara kepada petugas rekam medis, petugas rekam medis menyatakan bahwa jarak antar rak sempit sehingga ketika petugas akan mengambil maupun menyimpan berkas rekam medis pasien merasa kesulitan. Maka untuk ukuran jarak antar rak penyimpanan belum ergonomi. Hal tersebut mengakibatkan ruang gerak petugas dalam mengambil dan menyimpan berkas rekam medis menjadi terbatas dan petugas harus bergantian dalam melakukan pengambilan berkas rekam medis pada tempat yang sama. Pengukuran jarak antar rak penyimpanan berguna untuk mempermudah dalam lalu lalang petugas rekam medis dalam melakukan pengambilan maupun penyimpanan dokumen rekam medis secara bersamaan tanpa mengalami hambatan.

\section{B. Pembahasan}

Ergonomi adalah ilmu, seni dan penerapan teknologi untuk menyerasikan atau menyeimbangkan antara fasilitas yang digunakan baik dalam beraktivitas maupun istirahat dengan kemampuan dan keterbatasan manusia baik fisik maupun mental sehingga kualitas hidup secara keseluruhan menjadi lebih baik (Tarwaka \& Sudiajeng, 2004).

Ruang penyimpanan rekam medis memiliki makna penting sehubungan dengan riwayat penyakit seseorang serta kerahasiaan yang tercantum di dalamnya. Oleh karena itu, metode penyimpanannya wajib diatur sedemikian rupa supaya kerahasiaannya bisa terpelihara. Terciptanya kemudahan petugas rekam medis dalam pengambilan dan penyimpanan dokumen rekam medis terdapatnya tata ruang penyimpanan yang ergonomis cocok dengan dimensi jangkauan ukuran badan manusia (Putri, Triyanti, \& Setiadi, 2014).

Sistem penyimpanan rekam medis di RS Hermina Arcamanik Bandung dilakukan secara sentralisasi yaitu sistem penyimpanan dimana semua rekam medis pasien disimpan dalam satu berkas dan satu tempat, baik untuk rawat jalan maupun rawat inap. Sistem penjajaran yang digunakan di RS Hermina Arcamanik Bandung adalah Terminal Digit Filing (TDF), yaitu sistem penyimpanan rekam medis dengan mensejajarkan folder rekam medis berdasarkan urutan nomor rekam medis pada dua angka atau dua digit kelompok terakhir.

RS Hermina Arcamanik Bandung memiliki ruang penyimpanan dengan rak penyimpanan berjumlah 160 rak, tempat penyimpanan dokumen rekam medis menggunakan rak terbuka yang masing-masing rak tersebut terdapat 6 sub rak. Petugas yang melakukan pengambilan dan penyimpanan rekam medis sebanyak 4 orang dengan jenis kelamin perempuan dan laki-laki. Petugas rekam medis bekerja dengan kondisi ruangan tempat penyimpanan yang kurang memadai. Berikut merupakan gambar kondisi ruang penyimpanan dokumen rekam medis di RS Hermina Arcamanik Bandung. 


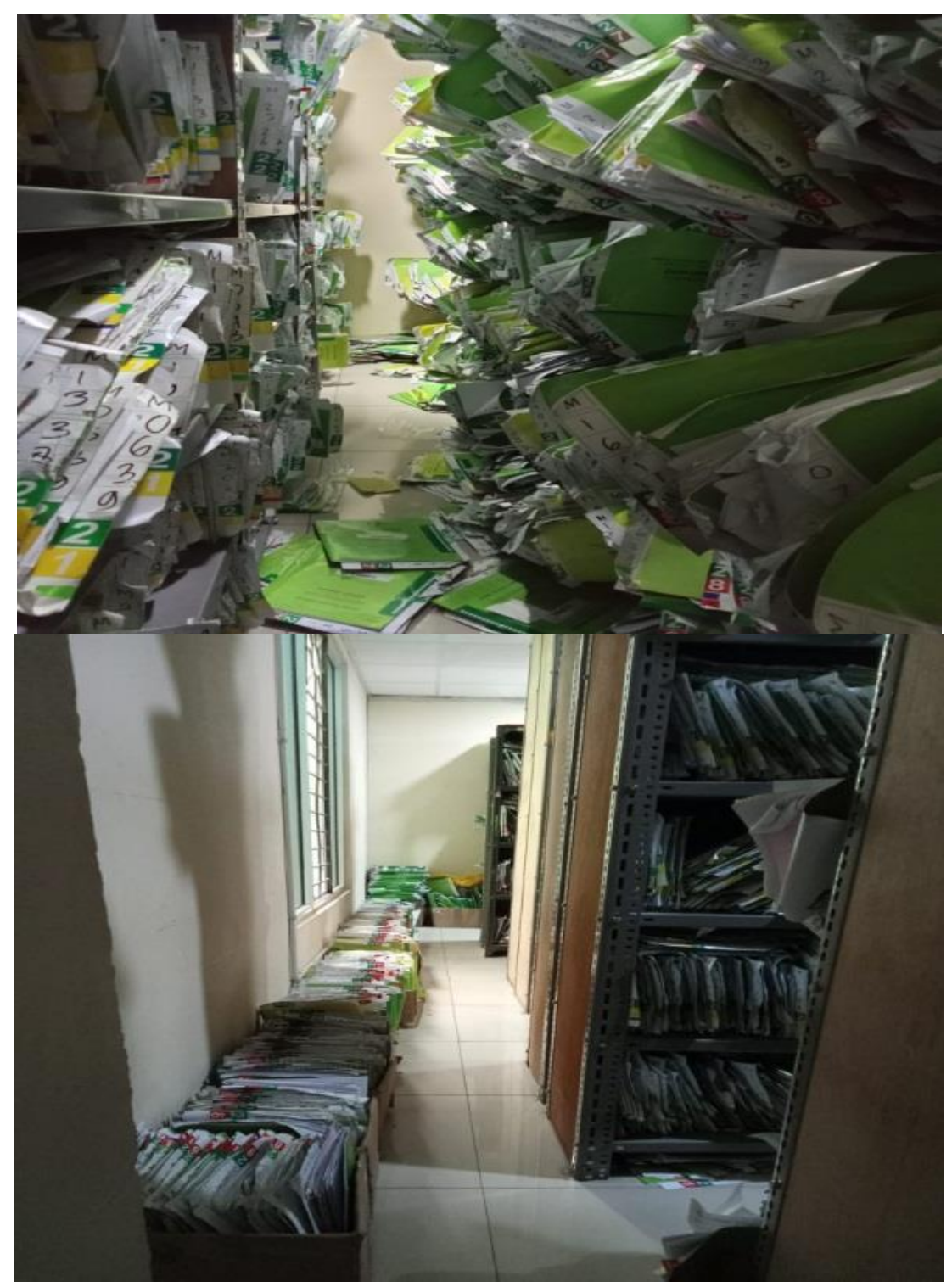

Berdasarkan dari gambar diatas terlihat bahwa tata ruang yang masih belum baik, banyak dokumen rekam medis yang di simpan di lantai/kardus tidak pada rak penyimpanan, di dalam ruang penyimpanan dokumen rekam medis di Unit Rekam Medis Hermina Arcamanik Bandung terdapat 160 rak penyimpanan rekam medis sedangkan jumlah rekam medis yang tidak masuk rak dari tahun 2012 - 2018 yaitu 33275 dokumen rekam medis. Hal ini menunjukkan bahwa masih banyak dokumen rekam medis yang belum tersimpan di rak penyimpanan. Dokumen rekam medis yang tersimpan di rak dengan tidak rapi serta masih banyak dokumen rekam medis yang sengaja dipaksa dimasukan pada rak meskipun rak sudah penuh.

Guna membantu petugas dalam mengambil rekam medis di rak paling atas tidak disediakan tangga/kursi pijakan di setiap lorong rak, sehingga mengharuskan petugas memanjat rak untuk mengambil rekam medis yang tidak terjangkau. Hal tersebut kurang aman sehingga memungkinkan adanya risiko jatuh, terkilir dan sebagainya.

Seperti gambar berikut: 


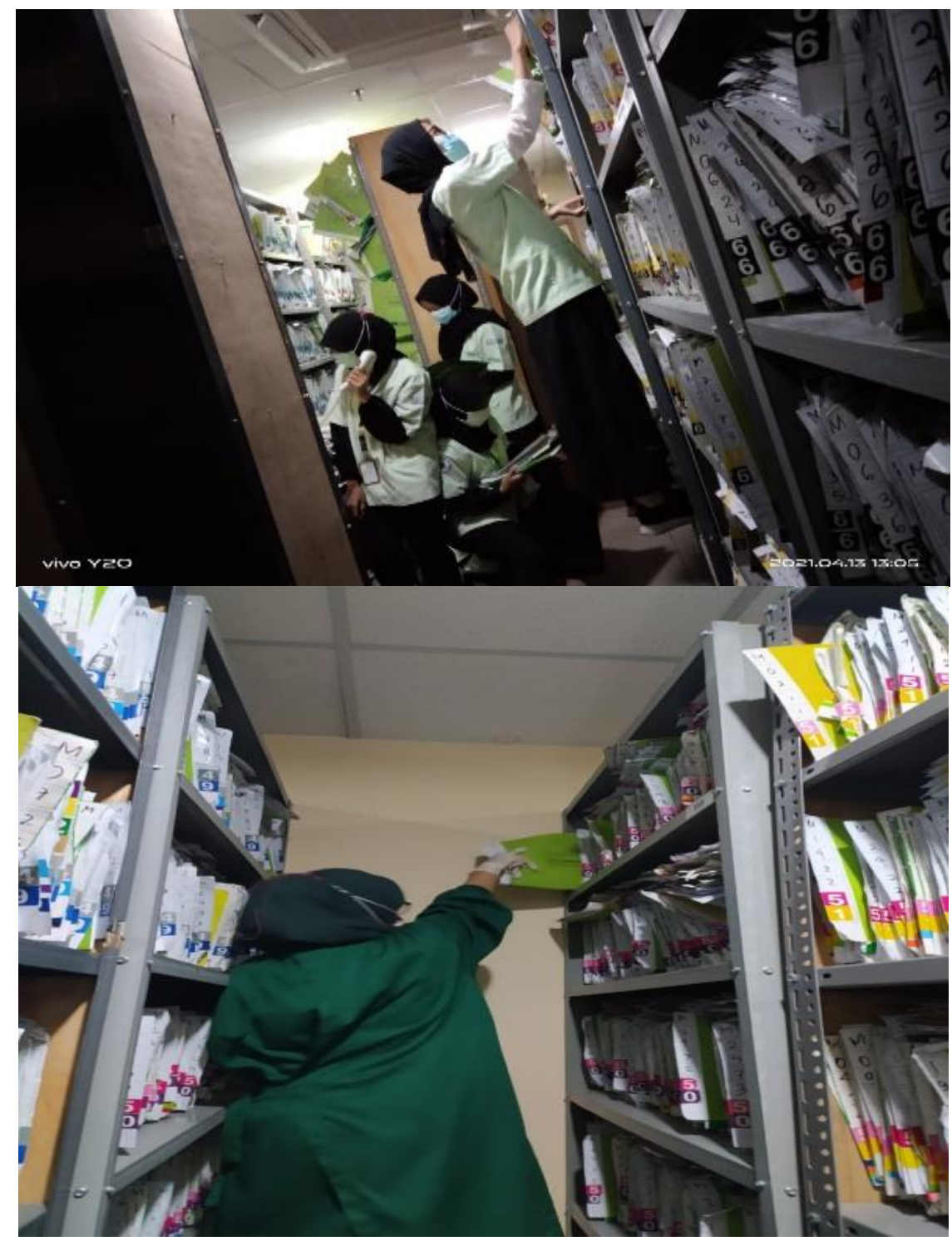

Selain itu juga kesulitan dalam pengambilan rekam medis karena jarak antara rak yang satu dengan yang lainnya begitu sempit, sehingga petugas kesulitan melakukan pengambilan dan penyimpanan secara bersamaan di tempat yang sama (harus bergantian dalam melakukan pengambilan maupun penyimpanan dokumen rekam medis). Hal ini tentu menyulitkan ruang gerak petugas karena jarak antar rak yang begitu sempit, serta menimbulkan risiko dokumen rekam medis mudah robek ataupun jatuh ketika tersenggol petugas rekam medis pada saat pengambilan maupun penyimpanan dokumen rekam medis.

Seperti gambar berikut:

Tinjauan Aspek Ergonomi Tata Ruang Penyimpanan Rekam Medis di Rs Hermina Arcamanik Bandung 


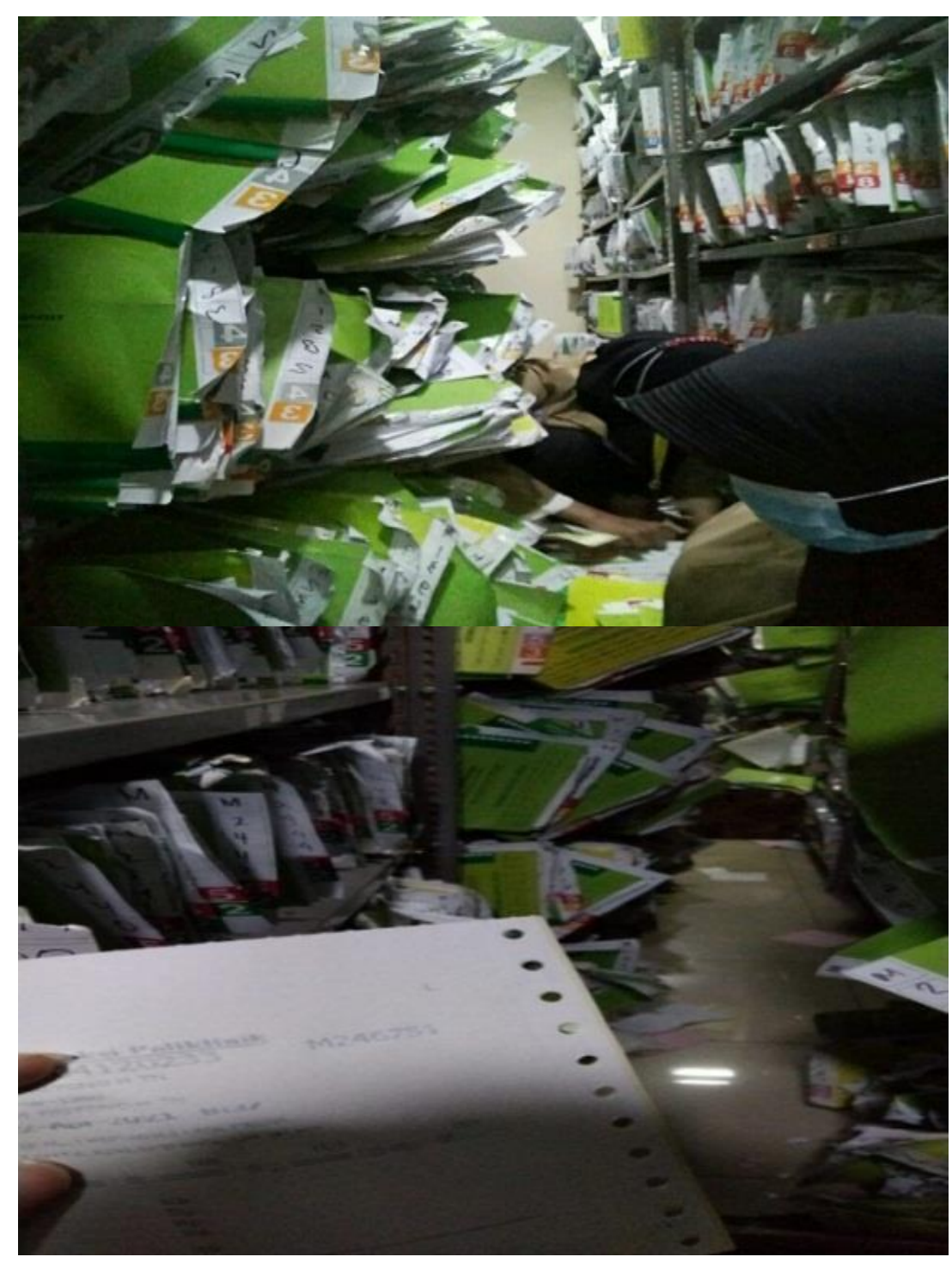

Standar jarak ideal untuk akses jalan petugas antara satu rak lemari dengan rak lemari lainnya kurang lebih $180 \mathrm{~cm}-200 \mathrm{~cm}$, sedang lorong di bagian sub rak $80 \mathrm{~cm}-$ $100 \mathrm{~cm}$ (Rustiyanto \& Rahayu, 2011). Menurut Depkes (2006), jarak antara dua buah rak untuk lalu-lalang dianjurkan selebar $90 \mathrm{~cm}$ (DepKes, 2006).

\section{KESIMPULAN $[\mathrm{sk} 1]$}

Berdasarkan hasil penelitian yang dilakukan di RS Hermina Arcamanik Bandung dapat disimpulkan bahwa aspek ergonomi ruangan penyimpanan di RS Hermina Arcamanik Bandung dari segi pengelolaan dan perlengkapan sudah sesuai dengan teori yang ada, hanya terdapat kendala pada ketersediaan jumlah alat bantu pijakan. Suhu di ruang penyimpanan di RS Hermina Arcamanik Bandung sudah ideal, tingkat kebisingan rendah, dan pencahayaan sudah merata.

Jenis dan ukuran rak ruangan penyimpanan rekam medis sudah ergonomi. Luas ruangan penyimpanan belum ergonomi karena tidak sesuai dengan standar menurut ilmu ergonomi dan ruangan penyimpanan pun dibagi menjadi dua ruangan yang terpisah. Jarak antar rak terbuka di ruangan penyimpanan rekam medis masih belum ergonomi 
dikarenakan keterbatasan ruangan penyimpanan berkas rekam medis dan petugas masih kesulitan saat mengambil maupun menyimpan dokumen rekam medis karena jarak antar rak yang begitu sempit. Petugas yang mengambil rekam medis di rak paling atas tidak disediakan tangga/kursi pijakan di setiap lorong rak, sehingga mengharuskan petugas memanjat rak untuk mengambil rekam medis yang tidak terjangkau, seperti di rak paling atas. Hal ini akan membahayakan para petugas dan resiko akan jatuh. Sebaiknya sediakan tangga/kursi pijakan di setiap lorong rak untuk mempermudah pengambilan rekam medis yang tidak terjangkau.

\section{BIBLIOGRAFI}

Darmawan, Mochammad Arief, Roziqin, Mochammad Choirur, \& Erawantini, Feby. (2020). Desain Tata Ruang Filing Poliklinik JKN Berdasarkan Lingkungan Fisik yang Ergonomis. J-REMI: Jurnal Rekam Medik Dan Informasi Kesehatan, I(3), 186197.

DepKes, R. I. (2006). Petunjuk Teknis Peyelenggaraan Rekam Medis, Direktorat Jenderal Pelayanan Medik. Jakarta: DepKes RI.

Depkes RI. (2014). Peraturan Menteri Kesehatan Republik Indonesia Nomor 9 Tahun 2014 Tentang Klinik. Menteri Kesehatan Republik Indonesia Peraturan Menteri Kesehatan Republik Indonesia, Nomor 65(879), 2004-2006.

Djohar, Djusmalinar, Oktavia, Nova, \& Damayanti, Fitrah Tri. (2018). Analisis Penyebab Terjadinya Missfile Dokumen Rekam Medis Rawat Jalan di Ruang Penyimpanan (Filling) RSUD Kota Bengkulu Tahun 2017. Jurnal Manajemen Informasi Kesehatan Indonesia (JMIKI), 6(2), 79-86.

Fanny, Nabilatul. (2017). Hubungan Antara Keergonomisan Meja dan Kursi dengan Kinerja Petugas di Tempat Pendaftaran Pasien RS PKU 'Aisyiyah Boyolali. Indonesian Journal On Medical Science, 4(1).

Harahap, Aisyah Aulia. (2019). Perancangan Tempat Perendaman Pembuatan Tahu Sumedang Yang Ergonomis Menggunakan Workplace Ergonomic Risk Assessment (Wera). Universitas Islam Negeri Sultan Syarif Kasim Riau.

Hatta, G. R. (2013). Pedoman Manajemen Informasi Kesehatan Di Sarana Pelayanan Kesehatan. Jakarta: UI-Press.

Hutabarat, Julianus. (2017). Dasar Dasar Pengetahuan Ergonomi. Media Nusa Creative.

Jepisah, Doni. (2020). Faktor-Faktor Yang Mempengaruhi Ergonomi Ruangan Filling Terhadap Akses Petugas Rekam Medis Di Rsud Siak Tahun 2018. Menara Ilmu, 14(1).

Mathar, Irmawati, Nurlina, Nurlina, \& Puspa, Puspa. (2019). Perancangan Ulang Tata Kelola Ruang Filling Berdasarkan Ilmu Ergonomi Di Puskesmas Banjarejo Kota Madiun. SMIKNAS, 171-181.

Murodi, Murodi. (2018). Analisis Pekerja Manual Material Handling (MMH) Product Finish Good Untuk Mencegah Musculoskeletal Disorders (Studi Kasus di PT. Martina Berto, Tbk, Jakarta). Universitas Bhayangkara Jakarta Raya.

Notoamodjo Soekidjo. (2018). Metodologi Penelitian Kesehatan. Jakarta: PT. Rineka Cipta.

Putri, Anggy Pramudhita, Triyanti, Endang, \& Setiadi, Dedi. (2014). Analisis Tata Ruang Tempat Penyimpanan Dokumen Rekam Medis Pasien Ditinjau dari Aspek Antropometri Petugas Rekam Medis. Jurnal Manajemen Informasi Kesehatan Indonesia (JMIKI), 2(2).

RI, Depkes. (2006). Pedoman Penyelenggaraan \& Prosedur Rekam Medis Rumah Sakit di Indonesia Revisi II. REVISI II.

Rustiyanto, Efile://G:/ALL REFERENCE/rustiyanyo. risr., \& Rahayu, Warih Ambar.

Tinjauan Aspek Ergonomi Tata Ruang Penyimpanan Rekam Medis di Rs Hermina

Arcamanik Bandung 
(2011). Manajemen Filing Dokumen Rekam Medis dan Informasi Kesehatan. Yogyakarta: Politeknik Kesehatan Permata Indonesia.

Siyoto, Sandu, \& Sodik, Muhammad Ali. (2015). Dasar metodologi penelitian. Literasi Media Publishing.

Suardi, Rahmi Primagusti, \& Budi, Savitri Citra. (2013). Perancangan Ulang Ruang Filing Berdasarkan Ilmu Ergonomi di Rumah Sakit Panti Rini Kalasan. Jurnal Manajemen Informasi Kesehatan Indonesia (JMIKI), 1(2).

Subandi, Subandi. (2011). Deskripsi Kualitatif Sebagai Satu Metode Dalam Penelitian Pertunjukan. Harmonia Journal of Arts Research and Education, 11(2), 62082.

Tarwaka, Solichul, \& Sudiajeng, Lilik. (2004). Ergonomi untuk keselamatan, kesehatan kerja dan produktivitas. Uniba, Surakarta, 34-50.

(C) 2021 by the authors. Submitted for possible open access publication under the (c) (7) (2) terms and conditions of the Creative Commons Attribution (CC BY SA) license (https://creativecommons.org/licenses/by-sa/4.0/). 